\title{
Response of zinnia cultivars to boron levels
}

\author{
Bahar Ali ${ }^{1}$, Noor ul Amin ${ }^{1}$, Mohammad Wasiullah Khan ${ }^{1 *}$, Faiza \\ Aman ${ }^{1}$, Iqbal Hussain ${ }^{2}$, Talha Jan ${ }^{2}$ and Muhammad Naeem Khan ${ }^{1}$ \\ 1. Department of Horticulture, the University of Agriculture, Peshawar-Pakistan \\ 2. Department of Agronomy, the University of Agriculture, Peshawar-Pakistan \\ *Corresponding author's email: wasikhan361@ aup.edu.pk \\ Citation \\ Bahar Ali, Noor ul Amin, Mohammad Wasiullah Khan, Faiza Aman, Iqbal Hussain, Talha Jan and Muhammad \\ Naeem Khan. Response of zinnia cultivars to boron levels. Pure and Applied Biology. Vol. 7, Issue 1, pp42-49. \\ http://dx.doi.org/10.19045/bspab.2018.70006
}

\begin{tabular}{llll}
\hline \hline Received: 23/10/2017 & Revised: 22/12/2017 & Accepted: 28/12/2017 & Online First: 01/01/2018 \\
\hline \hline
\end{tabular}

\section{Abstract}

An experiment was conducted to study the 'Response of zinnia cultivars to boron levels'" at ornamental Nursery, Department of Horticulture, The University of Agriculture, Peshawar during 2014. The experiment was Completely Randomized Design (CRD) having three replications. There were four boron levels $\left(0 \mathrm{~kg} \mathrm{ha}^{-1}, 1 \mathrm{~kg} \mathrm{ha}^{-1}, 2 \mathrm{~kg} \mathrm{ha}^{-1}, 3 \mathrm{~kg} \mathrm{ha}^{-1}\right)$, and three zinnia cultivars (Coral dream, Yellow dream, Pink dream). The result showed that both boron and zinnia cultivars significantly effect in all parameters. Maximum number of flowers plant ${ }^{-1}$ (18.60), flower diameter $(8.71 \mathrm{~cm})$, fresh flower weight $(9.7 \mathrm{~g})$, plant height $(40.04 \mathrm{~cm})$, root length $(16.3 \mathrm{~cm})$ and dry flower weight $(1.90 \mathrm{~g})$ were observed in plots, supplied with boron at rate of $2 \mathrm{kgha}^{-1}$. Among cultivars Coral dream cultivar showed maximum plant height $(35.7 \mathrm{~cm})$, flowers number plant ${ }^{-1}(15.04)$, fresh flower weight $(8.5 \mathrm{~g})$, flower diameter $(8.32 \mathrm{~cm})$, root length $(13.28 \mathrm{~cm})$, and dry flower weight $(1.60 \mathrm{~g})$. The interaction between boron levels and zinnia cultivars was significant for the observed parameters except plant height. Among different treatments zinnia cultivars, Coral dream and Yellow dream treated with boron $2 \mathrm{~kg} \mathrm{ha}^{-}$ ${ }^{1}$ should be recommended for maximum growth and flowering attributes under the agroclimatic conditions of Peshawar.

Keywords: Boron; Cultivars; Zinnia

\section{Introduction}

In the economy of Pakistan agriculture is a basic role. It contributes $26 \%$ of Gross dmestic products (GDP) and $45 \%$ of labor force is it, while almost $67.5 \%$ of population is directly or indirectly based on agriculture for their survival. Among agriculture ton growing area is floriculture which deals with production, management and marketing of ornamental plants and this great participate to improve the market and net return to the growers. Production of superior quality flowering plants needs special attention. Zinnia are produced in
Patoki and Peshawar and other part of Pakistan.

Zinnia elegans is another glorious flower of summer season.it is originated from Mexico. It belongs to family Composite and is native to Mexico and Central America. Zinnia flowers exhibit bright colors with sturdy stems and reasonably long vase life and that's why gaining fame as specialty cut flower [1]. Zinnia is a dicot herbaceous plant and prefers warm climate and have a height from $15-100 \mathrm{~cm}$. Zinnia leaves are sand papery in texture, contrary, generally stalk less (sessile), pale to middle 
green in colour and having different forms linear to ovate [2].

It's flower in solitary with different appearances, from a single row of petals, to dome shape with various colors, such as bronze, pink, white, orange, scarlet, maroon, mauve, yellow, apricot, red, purple and lilac. Some flowers are striped, speckled or beclouded. Flowers are available in different forms including single, double and semi-double and also in "pompon" forms that resemble dahlias [2]. Zinnias are popular garden flowers, grown from seed. Seeds are sown in pots to raise nursery and then transplanted to field. Plant required food for their growth and development like all other living things.

By utilizing fertilizers containing other micronutrients and boron, quality of crops increases and lack of these elements declines plant photosynthesis and wipe out RNA, also amount of protein and carbohydrates synthesis decreases and hence the performance and quality of crop decreases [3]. Like the other nutrient, Boron plays an important role in the production of any crop in term of yield, quality and control of some diseases. Boron plays an essential role in the development and growth of new cells in the plant meristem, proper pollination and fruit or seed set, Translocation of sugar, starches, nitrogen, and phosphorus, synthesis of amino acids and protein, regulation of carbohydrate metabolism and stabilize the oxidative system in plants. Since it is not readily translocated from older to actively growing tissues, the first visual deficiency symptom is cessation of the growth of the terminal bud, followed shortly thereafter by death of young leaves. Flowering and fruit development are also restricted by shortage of this nutrient. In boron deficient plants the first leaves become pale green, losing more color at the base then at the tip. Boron is actively involved in pollen germination and fruit, nut and seed formation. The boron requirement for flowering and seed set may be higher than that needed for vegetative growth. Boron can become limiting and critical periods during seed an flowers set due to drought periods which may reduce root activity, or rain fall has leach available boron from root zone in soil [4]. Boron plays a key role in a diverse range of plant functions including cell wall formation and stability, maintenance of structural and functional integrity of biological membranes, movement of sugar or energy into growing parts of plants, and pollination and seed set. Adequate B is also required for effective nitrogen fixation and nodulation in legume crops [5]. Boron is very essential for growth, yield and quality flower of plants. It helps in the development of cell wall, occurrence of cell division, formation of vascular bundle (phloem) and transport of $\mathrm{CH}_{2} \mathrm{O}$ (sugar). Foliar application of boron results in increase in setting of fruit, yield etc. it plays important role in N, P, Fats, hormone metabolism, soil absorption and photosynthesis [6]. The basic objectives was to study the effect of optimum level of boron on the quality, growth and flower production of Zinnia cultivar.

\section{Materials and methods}

The experiment "Response of zinnia cultivars to boron levels" was conducted at the Ornamental Nursery, Horticulture Department, The University of Agriculture Peshawar during, 2014.. Zinnias seed were sown in April, 2014 in pots with growing media of soil, silt and compost in ratio of $(1: 1: 1)$ Seeds were sprinkled with water on the basis of daily requirement. When the seedling developed two to three true leaves they were transplanted to pots filled with media containing soil, silt and compost. Uniform size and healthy seedling were chosen. Uniform culture practices were applied in each treatment during research. The experiment was conducted in two factors completely randomized design replicated three times. There were three dwarfing zinnia cultivars (Coral dreamland, Yellow dreamland and Pink dreamland) and four different levels (0, 1, 2 and $3 \mathrm{~kg} / \mathrm{ha}$ of boron were applied to each zinnia cultivars. For $1 \mathrm{kgha}^{-1}, 1256.4 \mathrm{mg}$ of boron 
have been taken and dissolved in $1200 \mathrm{ml}$ of water and then $10 \mathrm{ml}$ of water have been applied to each pot contained 2000 gm soil. For $2 \mathrm{~kg} \mathrm{ha}^{-1}, 2512.8 \mathrm{mg}$ of boron have been taken and dissolved in $1200 \mathrm{ml}$ of water and then $10 \mathrm{ml}$ of water have been applied to each pot contained 2000 gm soil. For $3 \mathrm{~kg}$ $\mathrm{ha}^{-1}, 3769.2 \mathrm{mg}$ of boron have been taken and dissolved in $1200 \mathrm{ml}$ of water and then $10 \mathrm{ml}$ of water have been applied to each pot contained 2000 gm soil.

\section{Results and discussion}

Number of flower plant $^{-1}$

The analysis of variance showed (Table 1) that boron significantly affected number of flowers, while the interaction was significant between B and Zinnia cultivars was significant (Figure 1). Increasing B level from 0 to $2 \mathrm{~kg} \mathrm{ha}^{-1}$ significantly enhanced flowers per plant and there after declines with further increase in B level. The most responsive variety was Coral dream which produce maximum flowers at $2 \mathrm{~kg} \mathrm{ha}^{-1}$ applied boron. Comparison of means showed that maximum number of flowers $(18.61 \%)$ was observed in plot that have received $2 \mathrm{~kg}$ boron $\mathrm{ha}^{-1}$ and flowed by $(13.13 \%)$ number of flowers in plot that received $1 \mathrm{~kg}$ boron $\mathrm{ha}^{-1}$. The minimum number of flowers $(11.74 \%)$ was observed in control plot. Coral dream cultivar (Table 2) showed the highest number (15.04) followed by yellow dream cultivar that showed (13.83) and lowest number of flower is (13.1) in pink cultivar. Interaction of mean showed that the coral dream cultivar showed highest number of flowers $(19.5 \%)$ in plots that supplied with boron $2 \mathrm{~kg} \mathrm{ha}^{-1}$, followed by pink dream cultivar which obtained $(18.3 \%)$ in plots treated with boron $2 \mathrm{~kg} \mathrm{ha}^{-1}$. the lowest number of flowers $(10.7 \%)$ was recorded in yellow dream cultivar was noted in control plots. These findings are in line with [7], who worked on the effect of boron and zinc on the growth and yield of gladiolus. They concluded that the uses of boron at the rate $2 \mathrm{~kg} \mathrm{ha}{ }^{-1}$ have significant effect on the number of flowers plant ${ }^{-1}$ of gladiolus as well highest number of flowers $(11.72 \%)$ produced. [8] who studied the effect of micronutrient $(\mathrm{Fe}, \mathrm{Zn}, \mathrm{B}$ and $\mathrm{Mn})$ on gerbera jamesonii, who reported that these micronutrient have significant effect on all parameter such as plant height, number of flower plant ${ }^{-1}$, flower weight. But have special effect on days to flowering decreasing the days to initiate flowers.

Table 1. Effect of boron $\left(\mathrm{kg} \mathrm{ha}^{-1}\right)$ on the growth of zinnia

\begin{tabular}{|c|c|c|c|c|c|c|}
\hline $\begin{array}{c}\text { Boron } \\
\text { (kg/ha) }\end{array}$ & $\begin{array}{l}\text { Number of } \\
\text { flower per } \\
\text { plant }\end{array}$ & $\begin{array}{l}\text { Flower } \\
\text { diameter } \\
\text { (cm) plant }{ }^{-1}\end{array}$ & $\begin{array}{l}\text { Fresh } \\
\text { flower } \\
\text { weight (g) } \text { plant }\end{array}$ & 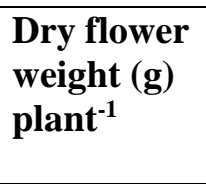 & $\begin{array}{l}\text { Plant } \\
\text { height (cm) } \\
\text { plant }^{-1}\end{array}$ & $\begin{array}{l}\text { Root } \\
\text { length }(\mathrm{cm}) \\
\text { plant }^{-1}\end{array}$ \\
\hline (0 & $11.76 \mathrm{c}$ & $7.7 \mathrm{c}$ & $7.4 \mathrm{~d}$ & $1.28 \mathrm{~d}$ & $30.02 \mathrm{c}$ & $7.61 d$ \\
\hline 1 & $13.13 b$ & $8.2 b$ & $8.0 \mathrm{c}$ & $1.44 \mathrm{c}$ & $31.08 \mathrm{c}$ & $12.83 \mathrm{~b}$ \\
\hline 2 & $18.60 \mathrm{a}$ & $9.34 \mathrm{a}$ & $9.7 \mathrm{a}$ & $1.90 \mathrm{a}$ & $40.04 a$ & $16.3 \mathrm{a}$ \\
\hline 3 & $11.98 \mathrm{c}$ & $8.14 b$ & $8.6 \mathrm{~b}$ & $1.59 \mathrm{~b}$ & $37.1 \mathrm{~b}$ & $11.12 \mathrm{c}$ \\
\hline $\begin{array}{c}\text { LSD } \\
(\mathbf{0 . 0 5})\end{array}$ & 0.36 & 0.18 & 0.23 & 0.04 & 0.67 & 0.46 \\
\hline
\end{tabular}

\section{Flower diameter $(\mathbf{c m})$}

The statistical analysis of (Table 1) data showed that boron significantly affected flower diameter $(\mathrm{cm})$, while there was no significant difference among the cultivars The interaction between cultivars and boron levels was also non-significant. The highest flower diameter $(9.34 \mathrm{~cm})$ was recorded in plots treated with $2 \mathrm{~kg}$ boron ha 1 , fllowed by flower diameter $(8.15 \mathrm{~cm})$ in plots applied with $1 \mathrm{~kg}$ boron $\mathrm{ha}^{-1}$, the lowest flower diameter $(7.75 \mathrm{~cm})$ was recorded in the control plots. Coral dream cultivar (Table 2) showed the highest flower diameter $(8.71 \mathrm{~cm})$ followed by $(8.42 \mathrm{~cm})$ flower diameter in yellow dream cultivar, the lowest $(7.93 \mathrm{~cm})$ diameter of flower was recorded in pink dream cultivar. Interaction of mean indicated that yellow dream cultivar showed highest flower 
diameter $(9.5 \mathrm{~cm})$ in plots treated with boron $2 \mathrm{~kg} \mathrm{ha}^{-1}$, followed by coral dream cultivar which gained $(9.4 \mathrm{~cm})$ at the level of boron $2 \mathrm{~kg} \mathrm{ha}{ }^{-1}$. The lowest flower diameter $(6.9 \mathrm{~cm})$ in pink dream cultivar was noted in control plots [9], studied the response of schefflera arboricola L. plant to foliar application of micronutrient $(\mathrm{Fe}$, $\mathrm{Zn}, \mathrm{B}, \mathrm{Mn}$ ) and recorded that these micronutrient have significant effect on all parameter, especially on flower diameter. The findings of current observation are in line with work of [5]. They concluded that boron at the rate of $2 \mathrm{kgha}^{-1}$ have significant effect on flower diameter of gladiolus. Halder noted that boron at the rate $2 \mathrm{kgha}^{-}$ ${ }^{1}$ increase the flower diameter of gladiolus.

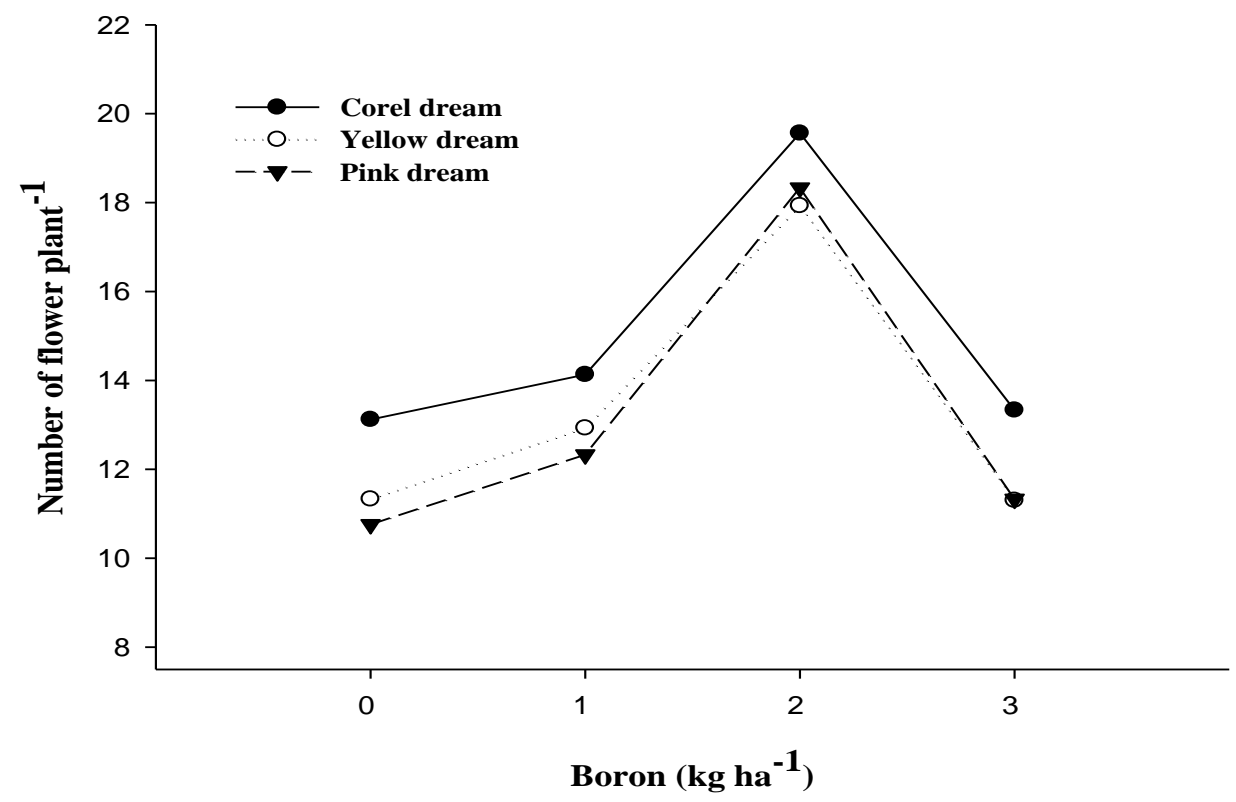

Figure 1. Number of flower plant ${ }^{-1}$ of zinnia as effected by the interaction of zinnia cultivars and boron

Table 2. Effect of Zinnia cultivars on the growth of zinnia

\begin{tabular}{|c|c|c|c|c|c|c|}
\hline $\begin{array}{c}\text { Zinnia } \\
\text { Cultivars }\end{array}$ & $\begin{array}{l}\text { Number of } \\
\text { flower } \\
\text { plant }^{-1}\end{array}$ & $\begin{array}{l}\text { Flower } \\
\text { diameter } \\
\text { (cm) }\end{array}$ & $\begin{array}{l}\text { Fresh } \\
\text { flower } \\
\text { weight }(\mathbf{g})\end{array}$ & $\begin{array}{l}\text { Dry flower } \\
\text { weight (g) }\end{array}$ & $\begin{array}{l}\text { Plant } \\
\text { height (cm) }\end{array}$ & $\begin{array}{l}\text { Root } \\
\text { length (cm) }\end{array}$ \\
\hline $\begin{array}{c}\text { Coral } \\
\text { dream }\end{array}$ & $15.043 \mathrm{a}$ & $8.71 \mathrm{a}$ & $8.5 \mathrm{a}$ & $1.60 \mathrm{a}$ & $35.7 \mathrm{a}$ & $13.283 \mathrm{a}$ \\
\hline $\begin{array}{c}\text { Yellow } \\
\text { dream }\end{array}$ & $13.383 \mathrm{~b}$ & $8.4 \mathrm{a}$ & $8.2 \mathrm{~b}$ & $1.54 \mathrm{~b}$ & $34.4 \mathrm{~b}$ & $12.01 \mathrm{~b}$ \\
\hline $\begin{array}{c}\text { Pink } \\
\text { dream }\end{array}$ & $13.192 \mathrm{~b}$ & $7.89 \mathrm{~b}$ & $8.1 \mathrm{~b}$ & $1.53 \mathrm{~b}$ & $34.43 \mathrm{~b}$ & $10.70 \mathrm{c}$ \\
\hline LSD (0.05) & 0.312 & 0.16 & 0.20 & 0.03 & 0.58 & 0.40 \\
\hline
\end{tabular}

\section{Dry flower weight (g)}

The analysis of findings (Table 1) shows that boron levels significantly affected the dry flower weight (g). While zinnia cultivar showed no significant response in flower weight. The interaction between cultivars and boron was also showed significant effect for dry flower weight (Figure 2) was was enhanced significantly by increase B levels from $0-22 \mathrm{~kg} \mathrm{ha}^{-1}$ therfore decline occurs. Increasing boron levels from 0-2 $2 \mathrm{~kg} \mathrm{ha}{ }^{-1}$, all the varities observed a 
significant increase in dry flower weight. Comparison of mean showed that highest dry flower weight $(1.9 \mathrm{~g})$ was observed in plots fertilized with $2 \mathrm{~kg}$ boron $\mathrm{ha}^{-1}$, followed by $(1.59 \mathrm{~g})$ of flower weight in plots supplied with $3 \mathrm{~kg}$ boron $\mathrm{ha}^{-1}$. The minimum weight $(1.3 \mathrm{~g})$ of flower was obtained in control plots. Coral dream cultivar (Table 2) showed the highest flower weight $(1.60 \mathrm{~g})$ followed with weight of flower $(1.54 \mathrm{~g})$ in yellow dream cultivar, while the lowest flower weight $(1.53 \mathrm{~g})$ was noticed in pink dream cultivar. Interaction of mean showed that coral dream cultivar showed the highest dry flower weight $(1.93 \mathrm{~g})$ in plots treated with $2 \mathrm{~kg}$ boron per ha, followed by yellow dream cultivar with weight of $(1.91 \mathrm{~g})$ treated with $2 \mathrm{~kg}$ boron per ha. The lowest flower weight $(1.23 \mathrm{~g})$ was observed in pink dream cultivar was noticed in control plots. The results are in with [10], who studied the effect of micronutrient $(\mathrm{B}, \mathrm{Fe}, \mathrm{Mn})$ on the growth and yield of marigold and reported that the optimal dose of these micronutrient have significant on dry flower weight of marigold.

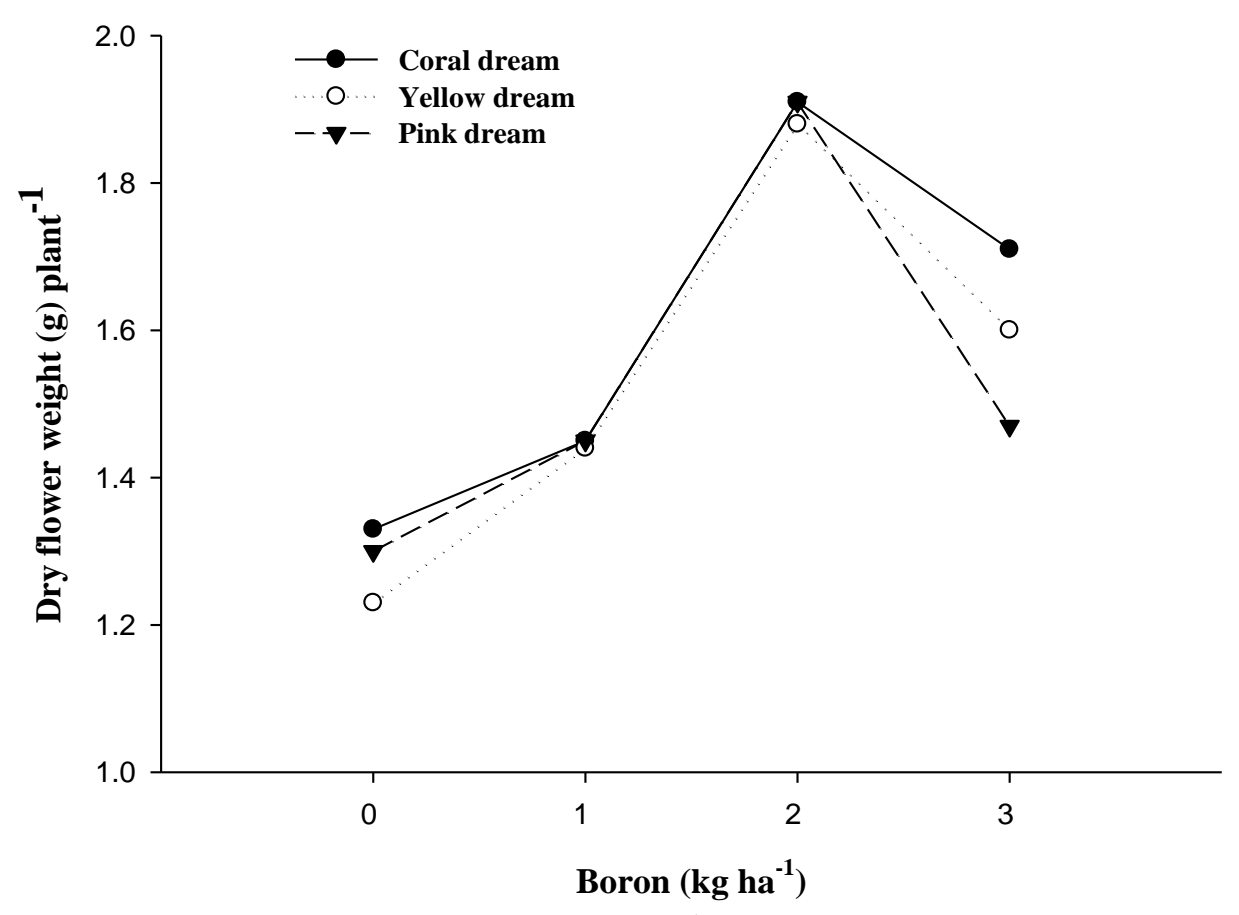

Figure 2. Dry flower weight (g) plant $^{-1}$ of zinnia as effected by the interaction of zinnia cultivars and boron

\section{Fresh flower weight $(\mathrm{g})$}

The analysis of variance showed (Table 1) that boron levels significantly affected the fresh flower weight (g), while zinnia cultivar showed non-significant response in flower weight, whereas interaction was also showed non-significant response. Comparison of mean showed that highest fresh flower weight $(9.76 \mathrm{~g})$ was observed in plots fertilized with $2 \mathrm{~kg}$ boron $\mathrm{ha}^{-1}$, followed by $(8.63 \mathrm{~g})$ of flower weight in plots fertilized with $3 \mathrm{~kg}$ boron ha ${ }^{-1}$, while the minimum weight $(7.2 \mathrm{~g})$ of flower was obtained in untreated plots. Coral dream cultivar (Table 2) showed the highest flower weight (10.6g) followed with weight of flower $(10.1 \mathrm{~g})$ in yellow dream cultivar, while the lowest flower weight $(6.5 \mathrm{~g})$ was noticed in pink dream cultivar. Interaction of mean showed that coral dream cultivar 
showed the highest fresh flower weight $(10.56 \mathrm{~g})$ in plots treated with $2 \mathrm{~kg}$ boron ha ${ }^{-}$ 1 , Followed by yellow cultivar with weight of $(9.46 \mathrm{~g})$ treated with $2 \mathrm{~kg}$ boron per ha. The lowest flower weight $(6.83 \mathrm{~g})$ in pink cultivar was noticed in control plots. The results are in line with[11], who studied the effect of micronutrient (B, Fe, Mn) on the growth and yield of marigold, they reported that the optimal dose of these micronutrient have significant on fresh flower weight of marigold.

\section{Plant height (cm)}

The analysis of variance shows (Table 1) that the boron levels significantly affected the plant height, whereas cultivars show non-significant response to plant height. The interaction between these factors was also non-significant. The tallest plants $(40.72 \mathrm{~cm})$ was noticed in plots supplied with $2 \mathrm{~kg}$ boron $\mathrm{ha}^{-1}$, followed by $(37.36 \mathrm{~cm})$ in a plots supplied with $3 \mathrm{~kg}$ boron $\mathrm{ha}^{-1}$, the shortest plant $(30.0 \mathrm{~cm})$ were noted in control plots. Coral dream cultivar (Table 2) showed the highest plant height $(42.00 \mathrm{~cm})$ followed with height of $(41.2 \mathrm{~cm})$ in yellow dream cultivar, while the shortest plant $(28.2 \mathrm{~cm})$ was noticed in pink dream cultivar, comparison of means show that the coral dream cultivar showed the highest plant height $(41.03 \mathrm{~cm})$ in plots treated with boron $2 \mathrm{~kg} \mathrm{ha}^{-1}$, followed by yellow dream cultivar which gained $(40.7 \mathrm{~cm})$ plant height at boron $2 \mathrm{~kg}$ per ha, The lowest plant height $(28.2 \mathrm{~cm})$ was noted in control plots. These findings are in line with [12], who studied the effect of boron, zinc, iron and manganese on dahlia flower, he noted that these micronutrients have significant effect on dahlia flower, and effect all parameter but have special effect on the root length of dahlia flower. These findings are also in line with [6] who worked on the effect of boron and zinc on the growth and yield of gladiolus. Who concluded that the use of boron at the rate 2 $\mathrm{kg} \mathrm{ha}^{-1}$ have significant effect on the plant height of gladiolus, as the highest plant $(70.88 \mathrm{~cm})$ was observed. These results are also in line with [10] who studied the effect of micronutrient such as ( $\mathrm{Fe}, \mathrm{Zn}, \mathrm{Mn}, \mathrm{B})$ on Gerbera jamesonii, he noted that these micronutrients have significant effect on the plant height of gerbera.

\section{Root length (cm)}

Analysis of data show (Table 1) that boron has significant effect on root length, additionally the cultivars show significant response in root length, whereas the interaction between $\mathrm{B}$ and Zinnia cultivars was significant (Figure 3). Increasing B level from 0 to $2 \mathrm{~kg} \mathrm{ha}^{-1}$ significantly enhanced root length $(\mathrm{cm})$ and there after declines with further increase in B level. The most responsive variety was Coral dream which produce maximum root length $(\mathrm{cm})$ at $2 \mathrm{~kg} \mathrm{ha}^{-1}$ applied boron. The maximum root length $(16.38 \mathrm{~cm})$ was recorded in plots that treated with boron $2 \mathrm{~kg} \mathrm{ha}{ }^{-1}$, Followed by $(12.83 \mathrm{~cm})$ in plot that received boron $1 \mathrm{kgha}^{-1}$, and the minimum root length $(7.62 \mathrm{~cm})$ was noted in control plots. The longest roots (Table 2) length $(13.28 \mathrm{~cm})$ was recorded in coral dream cultivar, followed by yellow dream cultivar $(12.07 \mathrm{~cm})$ and shortest roots $(10.7 \mathrm{~cm})$ were observed in pink dream cultivar. Interaction mean indicated that the coral dream cultivar showed the highest root length $(17.63 \mathrm{~cm})$ in plots treated with boron $2 \mathrm{~kg} \mathrm{ha}^{-1}$, followed by yellow dream cultivar which gained $(17.4 \mathrm{~cm})$ at the level of boron $2 \mathrm{~kg} \mathrm{ha}^{-1}$. The lowest root length $(7.06 \mathrm{~cm})$ in pink dream cultivar was observed in control plots. The findings are in line with [8], who studied the effect of micronutrients such as iron, copper, manganese and boron on the growth and quality of marigold, these micronutrient were applied in the concentration of $(0,200$, $400,600 \mathrm{ppm})$. These findings are also in line with [11], who studied the effect of boron, zinc, iron and manganese on dahlia flower. 


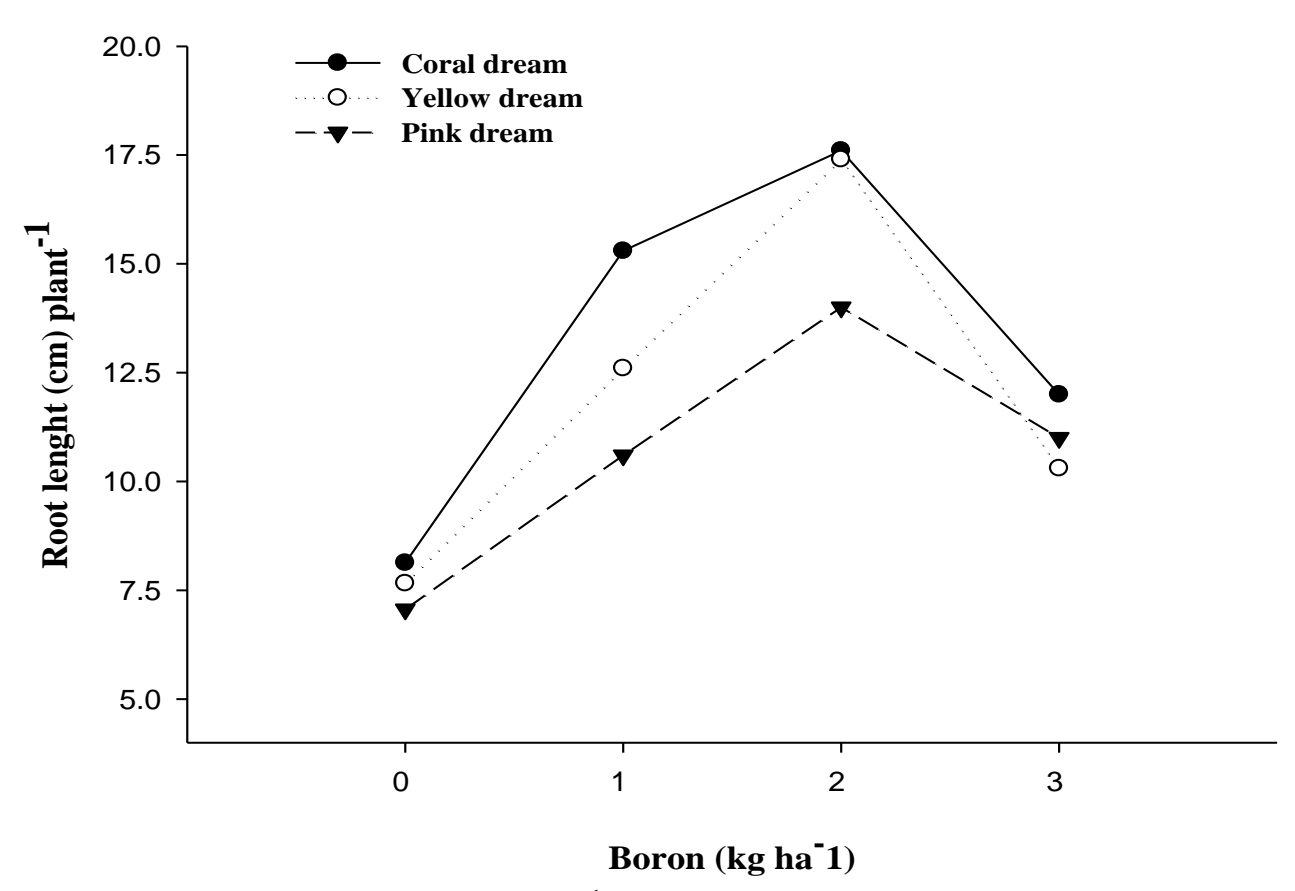

Figure 3. Root length $(\mathrm{cm})$ plant $^{-1}$ of zinnia as effected by the interaction of zinnia cultivars and boron

\section{Conclusions}

During the research period, the response of zinnia cultivars to boron levels was studied. It is concluded that boron at the rate of $2 \mathrm{~kg}$ $\mathrm{ha}^{-1}$ is more effective in increasing number of flower plant ${ }^{-1}$, fresh flower weight $(\mathrm{g})$, dry flower weight $(\mathrm{g})$, flower diameter $(\mathrm{cm})$, plant height $(\mathrm{cm})$ and root length $(\mathrm{cm})$. Similarly the response of coral dream cultivar and yellow dream cultivar was best in contrast to other cultivars in majority of growth parameters. Based on the conclusion it is recommended that the use of $2 \mathrm{~kg}$ boron $\mathrm{ha}^{-1}$ is recommended for better results regarding growth and flower production. Among the three cultivars i.e. coral dream, yellow dream, and pink dream, boron significantly effect on coral dream cultivar fresh flower weight and flower production hence coral dream cultivar and yellow dream are recommended for general production under agro-climatic condition of Peshawar.

\section{Authors' contributions}

Conceived and designed the experiments:, NU Amin, Performed the experiments: B Ali, Analyzed the data: MW Khan \& F
Aman, Contributed materials/ analysis/ tools: I Hussain, T Jan \& MN Khan, Wrote the paper: MW Khan \& F Aman.

\section{References}

1. Ahmad I \& Dole JM (2014). Homemade floral preservatives affect postharvest performance of selected specialty cut flowers. Horticulture Technology 24: 384-393.

2. Kirkbride, JH and Wicrsma JH (2007). Proposal to conserve the name Zinnia elegans against Z. Violacea. Taxon 56(3): 958-959.

3. Efe \& Yarpuz E (2011). The effect of boron application methods on seed cotton yield, lint and seed quality of cotton in east Mediterranean region of Turkey. African Journal of Biotechnology 10: 8782-8789.

4. Norberto B (2010). The Urban Gardner. 3(1): 1765-2094.

5. Marschner P (2012). Mineral Nutrition of Higher Plants, Plant Biology 4: 205223.

6. Verma SK \& Verma M (2007). A textbook of plant Physiology, Biochemistry and Biotechnology $6^{\text {th }}$ ed. 
S, Chand and Company Ltd. New Dehli, p. 115.

7. Halder NK, Ratiuddin M, Siddiky MA, Gomes R \& Begam KA (2007). Performance of gladiolus as influenced by boron and zinc. Pak J Bio Sci 10: 581585.

8. Khosa SS, Younis A, Rayit A, Yasmen $S$ \& Raiz (2011). Effect of micronutrient on growth of gerbera jamesonia. American-Eurasian J Agric \& Environ Sci 11: 736-757.

9. Younis A, Anjum S, Riaz A, Hameed M, Tariq U \& Ahsan M (2014). Production of quality dahlia (Dahlia variabilis cv. Redskin) flowers by efficient nutrients management. AmericanEurasian J Agric \& Environ Sci 14(2): 137-142.
10. Khosa SS, Younis A, Rayit A, Yasmen S \& Raiz (2011). Effect of micronutrient on growth of gerbera jamesonia. American Eurasim J Agric \& Environ. Sci 11: 736-757.

11. Mona MH, Quesni EL, Fatima ME \& Kandil MM (2010). Response of vegetative growth and chemical constituent of Schefflera arboricola L. plant to foliar application of inorganic Fertilizer (grow more) and ammonium nitrate at hubaria. Ozean. J of App Sci 3(1): 177-184.

12. Mehrab \& Yadegari (2013). Foliar Application of $\mathrm{Fe}, \mathrm{Cu}, \mathrm{Mn}$ and $\mathrm{B}$ on the growth yield and essential oil yield of marigold (Calendula efficinalis). $J$ Appl Sci \& Agri 8(5): 559-567. 